\title{
USE OF ALAR-ILIAC S2 SCREW TECHNIQUE IN SCOLIOSIS SECONDARY TO MYELOMENINGOCELE
}

\author{
UTILIZAÇÃO DA TÉCNICA DE PARAFUSO S2 ALAR-ILÍACO NA ESCOLIOSE SECUNDÁRIA \\ À MIELOMENINGOCELE
}

\section{UTILIZACIÓN DE LA TÉCNICA DE TORNILLO S2 ALAR-ILIACO EN LA ESCOLIOSIS SECUNDARIA A MIELOMENINGOCELE}

Coracy Gonçalves Brasil Neto, ${ }^{1},{ }^{3}$ Luiz Müller Ávila, ${ }^{2}$ Dulce Helena Grimm, ${ }^{2}$ Carlos Abreu de Aguiar, ${ }^{2}$ Luis Eduardo Munhoz da Rocha ${ }^{2}$

1. Fellow in Surgery of the Hospital Evangélico de Curitiba, PR, Brazil

2. Hospital Infantil Pequeno Príncipe, Curitiba, PR, Brazil

3. Hospital São Vicente de Curitiba - Curitiba, PR, Brazil

\begin{abstract}
Objective: To evaluate retrospectively the results related to the use of pelvic fixation with alar-iliac S2 screw in individuals with myelomeningocele. Methods: Retrospective study of cases surgically treated with this technique, between January 2015 and March 2018 at the Pequeno Principe Children's Hospital. Radiographic images and clinical records were analyzed in search of complications. Results: Twelve patients with mean age of 13.3 years were treated at the time of surgery. The mean follow-up was 11.5 months. The mean of the highest magnitude curve measured by the Cobb angle in the preoperative period was $83.8^{\circ}$; while in the last postoperative follow-up was $29.5^{\circ}$ (correction of $65 \%$ ). The mean pelvic obliquity was $23.1^{\circ}$ in the preoperative period and in the postoperative was $7.1^{\circ}$ (correction of $69 \%$ ). Only 2 cases $(17 \%)$ with complications associated with material failure at the level of sacroiliac fixation, due to the unilateral release of the head of the polyaxial S2 iliac screw. Conclusions: The technique of pelvic fixation in the scoliosis secondary to myelomeningocele with the use of S2 alar-iliac screws has shown satisfactory results, with only two complications (17\%) directly related to pelvic fixation in the operated cases. Level of Evidence IV; Series of Cases.
\end{abstract}

Keywords: Meningomyelocele; Bone Screws; Scoliosis; Surgery.

\section{RESUMO}

Objetivo: Avaliar retrospectivamente os resultados do uso da fixação pélvica com o parafuso S2 alar-iliaco em indivíduos portadores de mielomeningocele. Métodos: Estudo retrospectivo dos casos tratados cirurgicamente através desta técnica entre janeiro de 2015 e março de 2018 no Hospital Infantil Pequeno Príncipe. Foram analisados as imagens radiográficas e registro clínico no prontuário à procura de complicações. Resultados: Foram tratados 12 pacientes com média de idade de 13,3 anos no momento da cirurgia. A média de seguimento foi de 11,5 meses. A média da curva de maior magnitude medida pelo ângulo de Cobb no pré-operatório foi de 83, $8^{\circ}$; enquanto que no último seguimento pós-operatório foi de $29,5^{\circ}$ (correção de $65 \%$ ). A média da obliquidade pélvica foi de $23,1^{\circ}$ no pré-operatório e no pós-operatório de 7,1 (correção de 69\%). Foram observados apenas dois casos (17\%) com complicações associadas à falha do material ao nível da fixação sacroilíaca, devido soltura unilateral da cabeça do parafuso poliaxial de S2 alar-ilíaco. Conclusão: A técnica de fixação pélvica na escoliose secundária à mielomeningocele com uso de parafusos em S2 alar-ilíacos tem demonstrado resultados satisfatórios, havendo apenas duas complicações (17\%) diretamente relacionada à fixação pélvica nos casos operados. Nível de Evidência IV; Série de Casos.

Descritores: Mielomeningocele; Parafusos Ósseos; Escoliose; Cirurgia.

\section{RESUMEN}

Objetivo: Evaluar retrospectivamente los resultados del uso de la fijación pélvica con el tornillo S2 alar-ilíaco en individuos con mielomeningocele. Métodos: Estudio retrospectivo de los casos tratados quirúrgicamente a través de esta técnica entre enero de 2015 y marzo de 2018 en el Hospital Infantil Pequeno Príncipe. Fueron analizadas las imágenes radiográficas y los prontuarios en busca de complicaciones. Resultados: Se trataron quirúrgicamente a 12 pacientes con promedio de edad de 13,3 años. El promedio de seguimiento fue de 11,5 meses. El promedio de la curva de mayor magnitud medida por el ángulo de Cobb en el preoperatorio fue de $83,8^{\circ}$, mientras que en el último seguimiento postoperatorio fue de $29,5^{\circ}$ (corrección del 65\%). El promedio de la oblicuidad pélvica fue de $23,1^{\circ}$ en el preoperatorio y en el postoperatorio de 7,1 $1^{\circ}$ (corrección del 69\%). Se observaron sólo 2 casos (17\%) con complicaciones asociadas a la falla del material al nivel de la fijación sacroilíaca, debido a la soltura unilateral de la cabeza del tornillo poliaxial S2 alar-ilíaco. Conclusiones: La técnica de fijación pélvica en la escoliosis secundaria a la mielomeningocele con uso de tornillos en S2 alar-ilíacos ha demostrado resultados satisfactorios, habiendo apenas dos complicaciones (17\%) directamente relacionada a la fijación pélvica en los casos operados. Conclusiones (17\%) directamente relacionadas a la fijación pélvica en los casos operados. Nivel de Evidencia IV; Serie de Casos.

Descriptores: Meningomielocele; Tornillos Óseos; Escoliosis; Cirugía. 


\section{INTRODUCTION}

Myelomeningocele occurs due to a defect in the closure of the neural tube involving the spinal cord and meninges between the third and fourth weeks of the embryonic period. The pathology was first defined by Fraser (1929): "Condition of incomplete closure of one or more laminae of the spine, sometimes of the vertebral bodies, with or without protrusion of the spinal cord and the meninges." ${ }^{\prime}$

There is a strong association between myelomeningocele and spinal deformities that begin to appear in early infancy and become severe before 10 years of age. Among these deformities, scoliosis may develop in around $50 \%$ to $70 \%$ of patients. ${ }^{1,13}$ Age and the level of motor impairment are the principal determinants of the appearance of the deformity, reaching values from 88 to $100 \%$ in the thoracic level, 72 to $81 \%$ in the upper lumbar level, $3 \%$ in the lower lumbar level, and $9 \%$ in the sacral level. $2,3,14$

Pelvic obliquity is often related to spinal deformities and is attributed to muscle contractions above and below the pelvis, as well as to intrinsic deformities of the pelvic bones due to growth disturbances. ${ }^{4}$

The objectives of spinal arthrodesis surgery are the correction of the deformity and the restoration of the balance between the trunk and pelvis, thus influencing the improvement in the quality of life of these patients. ${ }^{5,13,14}$

Pelvic obliquity and lumbar kyphosis are indications for extending fixation to the pelvis. ${ }^{6,12}$ There are several pelvic fixation techniques described, and the Spine Service of the Hospital Infantil Pequeno Príncipe has used the S2 alar-iliac screw fixation technique.

\section{Objective}

The objective of this study is to retrospectively evaluate results related to the use of pelvic S2 alar-iliac screw fixation in individuals with myelomeningocele from data obtained prospectively from cases operated by the Spine Service of Hospital Infantil Pequeno Príncipe.

\section{METHODS}

We conducted a retrospective study of the data obtained prospectively from cases treated surgically via this technique between January 2015 and March 2018 at the Hospital Infantil. Twelve cases were reviewed by analyzing radiographic images and clinical records in search of complications.

The radiographs were reviewed by a single examiner looking for signs of material failure, such as loosening and breakage of the screws or rods at the level of pelvic fixation. The radiographic parameters were measured with the assistance of Surgimap Spine software, using the Cobb angle method to measure the degrees of the highest magnitude curve in pre- and postoperative panoramic anterior-posterior spinal radiographs and the Osebold method to measure pelvic obliquity. ${ }^{12}$

The surgical pelvic fixation technique using S2 alar-iliac screws was described by Sponseller et al. (2010). The reference for the point of entry is the point midway between the foramens of S1 and S2, at a distance of about $25 \mathrm{~mm}$ from the upper plateau of $\mathrm{S} 1,30 \mathrm{~mm}$ lateral to the midline of S1, and $20 \mathrm{~mm}$ lateral to the midline of S2, with a lateral angle of $40^{\circ}$ and a caudal angle of $40^{\circ} .6$

The case reports were reviewed in search of clinical reports of pain or ulceration at the level of S2 alar-iliac fixation, as well as the duration of follow-up.

This study was approved by the Hospital Infantil Institutional Review Board as number 65611917.3.0000.0097. All patients participating in the study signed the Informed Consent Form.

\section{RESULTS}

Six male (50\%) and six female (50\%) patients were treated surgically using the technique of S2 alar-iliac screw fixation (Figure 1). The mean age of the patients was 13.3 years (ranging from 9 to 17 years) at the time of surgery.

Mean follow-up was 11.5 months (ranging from 4 to 33 months). The clinical data are shown in Table 1.

The mean highest magnitude preoperative curve measured by the Cobb angle was $83.8^{\circ}$ (ranging from $56^{\circ}$ to $128^{\circ}$ ). The mean highest magnitude curve measured at the last postoperative follow-up was $29.5^{\circ}$ (between $0^{\circ}$ and $72^{\circ}$ ) with a mean correction of $65 \%$. Mean pelvic obliquity was $23.1^{\circ}$ (between $2^{\circ}$ and $57^{\circ}$ ) and $7.1^{\circ}$ (between $0^{\circ}$ and $17^{\circ}$ ) in the preoperative and postoperative periods, respectively, with a mean correction of $69 \%$. The data obtained are shown in Table 2.

Table 1. Clinical data of the surgically treated patients.

\begin{tabular}{c|c|c}
\hline \multicolumn{3}{|c}{ Clinical data } \\
\hline Sex & Male & $\begin{array}{c}\text { Female } \\
6(50 \%)\end{array}$ \\
\hline Age & $6(50 \%)$ & 6 years (between 9 and 17 years) \\
\hline Length of follow-up & 11.5 months (between 4 and 33 months) \\
\hline
\end{tabular}

Table 2. Radiographic data of the surgically treated patients

\begin{tabular}{c|c|c|c}
\hline Radiographic data & Preoperative & Postoperative & Correction \\
\hline Highest magnitude curve & Mean of $83.8^{\circ}$ & Mean of $29.5^{\circ}$ & Mean of $65 \%$ \\
\hline Pelvic obliquity & Mean of $23.1^{\circ}$ & Mean of $7.1^{\circ}$ & Mean of $69 \%$ \\
\hline Failure of material & \multicolumn{3}{|c}{2 cases $(17 \%)$} \\
\hline
\end{tabular}
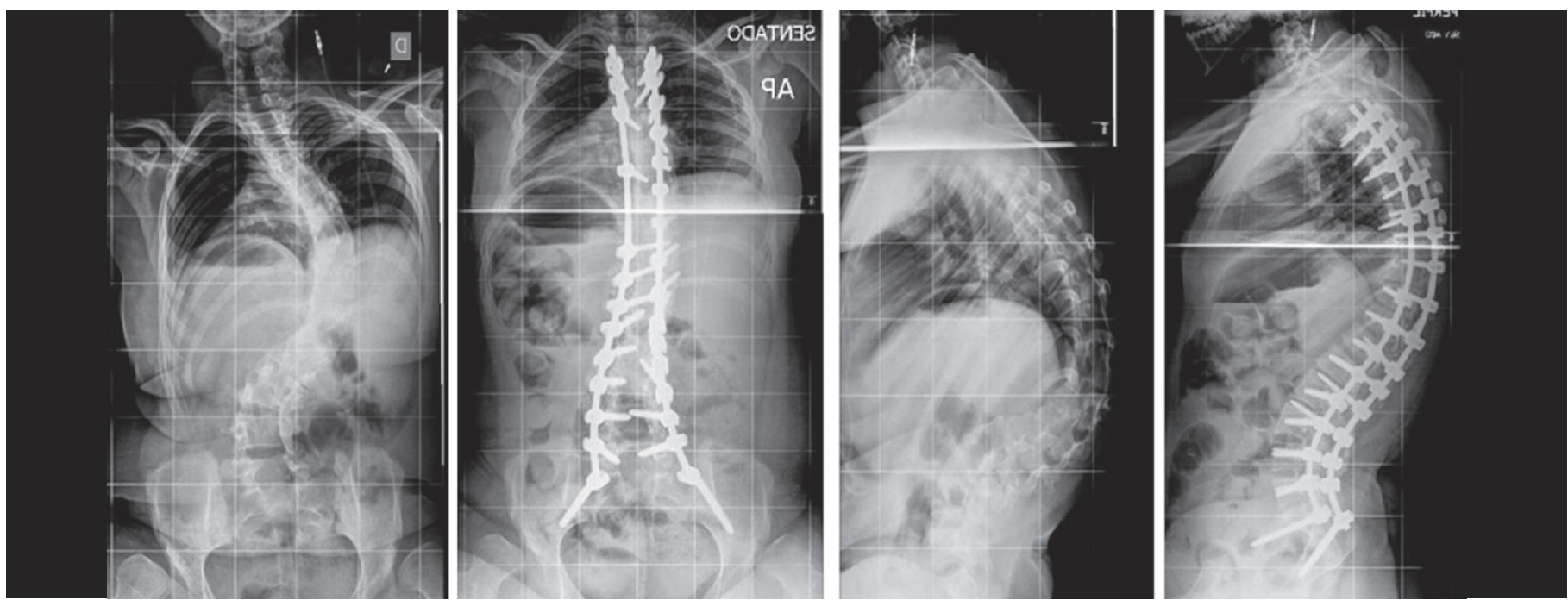

Figure 1. Preoperative and postoperative (at 5-month follow-up) anterior-posterior and lateral radiographs of a 16-year old patient treated surgically. The measurement of the highest magnitude curve was $71^{\circ}$ preoperatively and $9^{\circ}$ postoperatively, while pelvic obliquity measured $2^{\circ}$ prior to the surgery and $0^{\circ}$ following the surgery. 
Of the 12 cases submitted to the technique described, the radiographic analysis showed 2 cases (17\%) with complications associated with failure of the material at the level of sacroiliac fixation in S2. In one case, the head of the left polyaxial S2 alar-iliac screw had loosened at the 7-month follow-up and, in the other case, the 33-month control radiograph revealed loosening of the head of the right polyaxial S2 alar-iliac screw and breakage of the rod below the left S1 screw. We also observed that both these patients remained asymptomatic in the clinical follow-up, with no need for revision of the fixation.

There was one case of rod breakage at level L3-L4 in a patient who fell from the own height, defining a traumatic event as the cause of the complication, without compromising the S2 alar-iliac fixation.

Another complication reported, but not associated with the alar-iliac fixation, was of a patient who had a broken rod at level T11-T12 due to pseudoarthrosis, but without compromising the level S2 alar-iliac fixation, which required reintervention.

There were no clinical reports of wound complications or pain directly related to the material at the level of the $\mathrm{S} 2$ alar-iliac fixation.

\section{DISCUSSION}

Patients with myelomeningocele have a good chance of progress with spinal deformities that require surgical correction. Due to the neuromuscular nature of the pathology in the spine, pelvic obliquity usually accompanies the deformities and makes it necessary to include the pelvis in the fixation. 6,12

Among the several techniques described, the Hospital Infantil group has used S2 alar-iliac fixation. Modi et al. (2010) demonstrated that patients with neuromuscular scoliosis and pelvic obliquity greater than $15^{\circ}$ need pelvic fixation to prevent progression of the deformity. The study used the iliac screw technique and none of the patients included were diagnosed with myelomenigocele. ${ }^{7}$

Sharma et al. (2013) showed in their meta-analysis that the complication rate related to implants is around $12.51 \%$, reviewing 68 studies conducted over the previous 15 years that included patients with neuromuscular scoliosis. The revision rate, however, was around $7.87 \% .^{8}$ In our study, we observed a $17 \%$ rate (2 cases) of implant failure, without the need for fixation revision.

Montero et al. (2017) evaluated the results and technical complications of S2 alar-iliac fixation in 31 patients with neuromuscular scoliosis with an average follow-up of 9 months. Only 5 of these patients had a diagnosis of myelomeningocele. This study had a rate of complications related to the implant of $1.9 \%$, corresponding to one patient with an intra-articular screw in the hip. ${ }^{9}$

In their study using this technique in 38 patients with neuromuscular scoliosis with a minimum 5-year follow-up, Jain et al. (2017) reported correction of pelvic obliquity at $57 \%$, cases of infection in $11 \%$, and only one case of a unilateral fracture of the alar-iliac screw. This case series, however, included only 2 patients diagnosed with myelomeningocele. ${ }^{10}$

Comparing the sacral alar-iliac technique with fixation with iliac screws in the treatment of neuromuscular scoliosis, Shabtai et al. (2016) demonstrated that the rate of implant failure in the alar-iliac fixation group was only $7 \%$, corresponding to a rate $75 \%$ less than in the group with iliac screws. Even with a minimum follow-up of two years, the study included only one out of the 46 patients evaluated for the sacral alar-iliac technique with a diagnosis of myelomenigocele. ${ }^{11}$

Comparing the technique of sacral alar-iliac fixation with other methods, Sponseller et al. (2010) reported a better and significant correction of pelvic obliquity (70\% correction) with sacral alar-iliac fixation, although there was no difference in the final Cobb angle of the curve compared to those from the use of other techniques. There was only one case of revision of the sacral alar-iliac screws. ${ }^{15}$

The satisfactory results observed in this study were not previously found in other studies that generally present case series that include patients with countless neuromuscular pathologies, most of them with cerebral palsy. There is still a dearth of articles in the literature dealing with this technique specifically in patients with myelomeningocele.

The limitations of this study include follow-up time and the number of patients included, even though it is higher than that found in the literature.

\section{CONCLUSION}

The pelvic fixation technique in scoliosis secondary to myelomeningocele using S2 alar-iliac screws has yielded satisfactory results in our service, with only two complications of implant failure (17\%) directly related to pelvic fixation among the cases treated surgically.

All authors declare no potential conflict of interest related to this article.

CONTRIBUTION OF THE AUTHORS: Each author made significant individual contributions to this manuscript. CGBN (0000-0002-4486-8982) and LMA $(0000-0002-6244-8703)^{*}$ were the main contributors to the writing of the manuscript. CGNB, LMA, DHG $(0000-0002-1083-3677)^{\star}$, CAA(00000003-4310-6537**, and LEMR(0000-0002-1042-2886)* performed the patient surgeries, followed-up with the patients, and collected the clinical data. CGBN and LMA conducted the bibliographical research, reviewed the manuscript, and contributed to the intellectual concept of the study. ${ }^{*}$ ORCID (Open Researcher and Contributor ID).

\section{REFERENCES}

1. Stella G, Ascani E, Cervellati S, Bettini N, Scarsi M, Vicini M, et. al. Surgical Treatment of Scoliosis Associated with Myelomeningocele. Eur J Pediatr Surg. 1998;8(1):22- 5

2. Mackel JL, Lindseth RE. Scoliosis in myelodysplasia. J Bone Joint Surg Am. 1975; 57(7): 1031.

3. Mayfield JK.Severe spine deformity in myelodysplasia and sacral agenesis: an agressive surgical approach. Spine (Phila Pa 1976). 1981;6(5)498-509.

4. Miladi LT, Gahnem IB, Draoui MM, Zeller RD, Dubousset JF. lliosacral Screw Fixation for Pelvic Obliquity in Neuromuscular Scoliosis: a Long-Term Follow-up Study. Spine (Phila Pa 1976).1997:22(15):1722-9.

5. Peelle MW, Lenke LG, Bridwell KH, Sides B. Comparison of pelvic fxation techniques in neuromuscular spinal deformity correction: Galveston rod versus iliac and lumbosacral screws. Spine (Phila Pa 1976). 2006:31(20):2392-8.

6. Chang T, Sponseller PD, Kebaish KM, Fishman EK. Low Profile Pelvic Fixation: Anatomic Parameters for Sacral Alar-lliac Fixation Versus Traditional lliac Fixation. Spine (Phila Pa 1976). 2009;34(5):436-40.

7. Modi HN, Suh SW, Song HR, Yang JH, Jajodia N. Evaluation of pelvic fixation in neuromuscular scoliosis: a retrospective study in 55 patients. Int Orthop. 2010;34(1):89-96.

8. Sharma S, Wu C, Andersen T, Wang Y, Hansen ES, Bünger CE. Prevalence of complications in neuromuscular scoliosis surgery: a literature meta-analysis from the past 15 years. Eur Spine J. 2013;22(6):1230-49.

9. Montero CS, Meneses DA, Alvarado F, Godoy W, Rosero DI, Ruiz JM. Outcomes and complications of S2 alar iliac fixation technique in patients with neuromuscular scoliosis: experience in a third level pediatric hospital. J Spine Surg. 2017:3(4):519-24

10. Jain A, Sullivan BT, Kuwabara A, Kebaish KM, Sponseller PD. Sacral-Alar-lliac Fixation in Children with Neuromuscular Scoliosis: Minimum 5-Year Follow-UP. World Neurosurg. 2017:108:474-8.

11. Shabtai L, Andras LM, Portman M, Harris LR, Choi PD, Tolo VT, et al. Sacral Alar lliac (SAI) Screws Fail $75 \%$ Less Frequently Than Iliac Screws in Neuromuscular Scoliosis. J Pediatr Orthop. 2017;37(8):470-5.

12. Dayer R, Ouellet JA, Saran N. Pelvic fixation for neuromuscular scoliosis deformity correction. Curr Rev Musculoskeletal Med. 2012;5(2):91-101.

13. Guille JT, Sarwark JF, Sherk HH, Kumar SJ. Congenital and developmental deformities of the spine in children with myelomeningocele. J Am Acad Orthop Surg. 2006;14(5):294-302.

14. Martins MG, Rocha LEM, Aguiar CA, Pudles E, Sanzovo N. Resultados clínicos e radiográficos do tratamento cirúrgico da escoliose paralítica na mielomeningocele. Coluna/Columna. 2012;11(4):290-3

15. Sponseller PD, Zimmerman RM, Ko PS, Pull Ter Gunne AF, Mohamed AS, Chang $\mathrm{TL}$, et al. Low profile pelvic fixation with the sacral alar iliac technique in the pediatric population improves results at two-year minimum follow-up. Spine (Phila Pa 1976). 2010;35(20):1887-92. 